University of Nebraska - Lincoln

DigitalCommons@University of Nebraska - Lincoln

U.S. Environmental Protection Agency Papers

U.S. Environmental Protection Agency

2009

\title{
Finfish and aquatic invertebrate pathology resources for now and the future
}

Jan M. Spitsbergen

Oregon State University, spitsbej@onid.orst.edu

Vicki S. Blazer

U.S. Geological Survey

Paul R. Bowser

Cornell University

Keith C. Cheng

Pennsylvania State University - College of Medicine

Keith R. Cooper

Rutgers University

See next page for additional authors

Follow this and additional works at: https://digitalcommons.unl.edu/usepapapers

Spitsbergen, Jan M.; Blazer, Vicki S.; Bowser, Paul R.; Cheng, Keith C.; Cooper, Keith R.; Cooper, Timothy K.; Frasca, Salvatore Jr.; Groman, David B.; Harper, Claudia M.; (Mac) Law, Jerry M.; Marty, Gary D.; Smolowitz, Roxanna M.; St. Leger, Judy; Wolf, Douglas C.; and Wolf, Jeffrey C., "Finfish and aquatic invertebrate pathology resources for now and the future" (2009). U.S. Environmental Protection Agency Papers. 108. https://digitalcommons.unl.edu/usepapapers/108

This Article is brought to you for free and open access by the U.S. Environmental Protection Agency at DigitalCommons@University of Nebraska - Lincoln. It has been accepted for inclusion in U.S. Environmental Protection Agency Papers by an authorized administrator of DigitalCommons@University of Nebraska - Lincoln. 


\section{Authors}

Jan M. Spitsbergen, Vicki S. Blazer, Paul R. Bowser, Keith C. Cheng, Keith R. Cooper, Timothy K. Cooper, Salvatore Frasca Jr., David B. Groman, Claudia M. Harper, Jerry M. (Mac) Law, Gary D. Marty, Roxanna M. Smolowitz, Judy St. Leger, Douglas C. Wolf, and Jeffrey C. Wolf 
Review

\title{
Finfish and aquatic invertebrate pathology resources for now and the future ${ }^{\text {is }}$
}

\author{
Jan M. Spitsbergen a,b,*, Vicki S. Blazer ${ }^{c}$, Paul R. Bowser ${ }^{\mathrm{d}}$, Keith C. Cheng ${ }^{\mathrm{e}}$, Keith R. Cooper ${ }^{\mathrm{f}}$, Timothy K. Cooper ${ }^{\mathrm{g}}$, \\ Salvatore Frasca Jr. ${ }^{\text {, }}$, David B. Groman ${ }^{\mathrm{i}}$, Claudia M. Harper ${ }^{\mathrm{j}}$, Jerry M. (Mac) Law ${ }^{\mathrm{k}}$, Gary D. Marty ${ }^{1}$, \\ Roxanna M. Smolowitz ${ }^{\mathrm{m}}$, Judy St. Leger ${ }^{\mathrm{n}}$, Douglas C. Wolf ${ }^{\circ}$, Jeffrey C. Wolf ${ }^{\mathrm{p}}$
}

a Center for Fish Disease Research, 220 Nash Hall, Oregon State University, Corvallis, OR 97331, USA

${ }^{\mathrm{b}}$ Marine and Freshwater Biomedical Sciences Center, Oregon State University, Corvallis, OR 97331, USA

${ }^{c}$ National Fish Health Research Laboratory, US Geological Survey, 11649 Leetown Road, Kearneysville, WV 25430, USA

d Department of Microbiology and Immunology, College of Veterinary Medicine, Cornell University, Ithaca, NY 14853, USA

e The Jake Gittlen Cancer Research Foundation, Division of Experimental Pathology, Penn State College of Medicine, 500 University Drive, Hershey, PA 17033, USA

${ }^{\mathrm{f}}$ Department of Biochemistry and Microbiology, Rutgers University, 76 Lipman Drive, New Brunswick, NJ 08901, USA

g Department of Comparative Medicine, Hershey Medical Center, Pennsylvania State University, College of Medicine, 500 University Drive, Hershey, PA 17033, USA

${ }^{h}$ Department of Pathobiology and Veterinary Science, University of Connecticut, U-3089, 61 N, Eagleville Road, Storrs, CT 06269, USA

${ }^{\text {i }}$ Aquatic Diagnostic Services, Atlantic Veterinary College, University of Prince Edward Island, 550 University Avenue, Charlottetown, PE, Canada C1A 4P3

${ }^{\mathrm{j}}$ Amgen, Inc, Preclinical Division, One Kendall Square, Building 1000, Cambridge, MA 02139, USA

${ }^{\mathrm{k}}$ Population Health and Pathobiology, College of Veterinary Medicine, North Carolina State University, 4700 Hillsborough Street, Raleigh, NC 27606, USA

${ }^{1}$ Animal Health Centre, BC-MAL, 1767 Angus Campbell Road, Abbotsford, Canada BC V3G 2M3

${ }^{\mathrm{m}}$ Animal Health, New England Aquarium, Central Wharf, Boston, MA 02110, USA

${ }^{n}$ Pathology, Sea World San Diego, 500 Sea World Drive, San Diego, CA 92109, USA

- US Environmental Protection Agency, Research Triangle Park, NC 27711, USA

${ }^{\mathrm{p}}$ Experimental Pathology Laboratories, Inc, PO Box 169, Sterling, VA 20167, USA

\section{A R T I C L E I N F O}

\section{Article history:}

Received 2 June 2008

Received in revised form 30 September 2008

Accepted 1 October 2008

Available online 9 October 2008

\section{Keywords:}

Fish pathology

Aquatic model

Pathology training program

Invertebrate pathology

Standardized diagnostic criteria

Environmental sentinel

Histopathology

Aquatic animal medicine

\begin{abstract}
A B S T R A C T
Utilization of finfish and aquatic invertebrates in biomedical research and as environmental sentinels has grown dramatically in recent decades. Likewise the aquaculture of finfish and invertebrates has expanded rapidly worldwide as populations of some aquatic food species and threatened or endangered aquatic species have plummeted due to overharvesting or habitat degradation. This increasing intensive culture and use of aquatic species has heightened the importance of maintaining a sophisticated understanding of pathology of various organ systems of these diverse species. Yet, except for selected species long cultivated in aquaculture, pathology databases and the workforce of highly trained pathologists lag behind those available for most laboratory animals and domestic mammalian and avian species. Several factors must change to maximize the use, understanding, and protection of important aquatic species: 1) improvements in databases of abnormalities across species; 2) standardization of diagnostic criteria for proliferative and nonproliferative lesions; and 3) more uniform and rigorous training in aquatic morphologic pathology.
\end{abstract}

(C) 2008 Elsevier Inc. All rights reserved.

\section{Contents}

1. Introduction . . . . . . . . . . . . . . . . . . . . . . ....................250

2. Current training programs in aquatic pathology . . . . . . . . . . . . . . . . . . . . . . . . . . . . . . . . . . . . . . . . . . . . . . 250

2.1. North American Veterinary Anatomic Pathology programs emphasizing aquatic pathology . . . . . . . . . . . . . . . . . . . . . 251

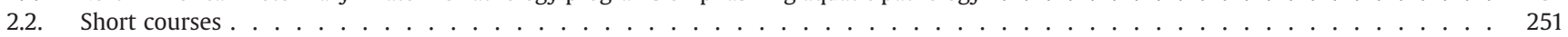

2.2.1. The AQUAVET Program . . . . . . . . . . . . . . . . . . . . . . . . . . . . . . . . . . . . . . . . . 251

2.2.2. Fish histology and histopathology . . . . . . . . . . . . . . . . . . . . . . . . . . . . . . . . . . . . . 251

2.2.3. Aquamed . . . . . . . . . . . . . . . . . . . . . . . . . . . . . . . . . . . . . . . . . . . . . . . 251

2.2.4. Shrimp Pathology Short Course: disease diagnosis and control in marine shrimp culture . . . . . . . . . . . . . . . . 251

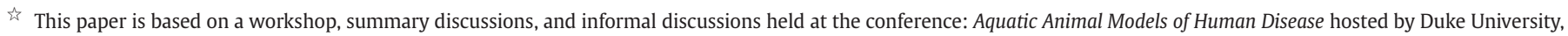
Durham, NC, USA, January 31-February 3, 2008. The opinions expressed here are those of individual scientists, not those of the organizations with which they are affiliated.

* Corresponding author. Center for Fish Disease Research, 220 Nash Hall, Oregon State University, Corvallis, OR 97331 , USA. Tel.: +1 541 737 5055 ; fax: +1 541 737 2166.

E-mail address: spitsbej@onid.orst.edu (J.M. Spitsbergen).
} 
2.2.5. Health and colony management of laboratory fish . . . . . . . . . . . . . . . . . . . . 251

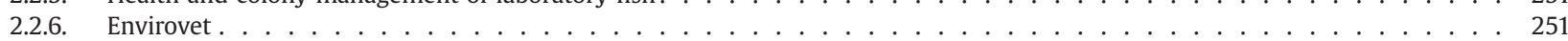

2.2.7. The Canadian Aquaculture Institute $(\mathrm{CAI}) \ldots \ldots \ldots \ldots \ldots$

2.2.8. Advanced coral tissue slide reading workshop. . . . . . . . . . . . . . . . . . . . . . . . . . . . . . 251

2.2.9. Other universities offering courses in aquatic animal pathology or histopathology of aquatic animals . . . . . . . . . . . . . 251

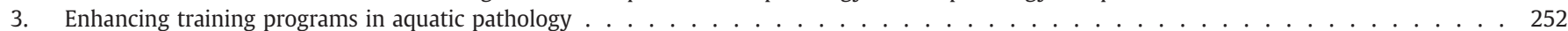

3.1. Additional pathology residency programs with training in aquatic species . . . . . . . . . . . . . . . . . . . . . . . . . 252

3.2. Enhancing training in histology, histopathology, and systemic pathology of aquatic species for biomedical scientists without

professional clinical medical training . . . . . . . . . . . . . . . . . . . . . . . . . . . 252

3.3. Need for specific training in toxicologic pathology of aquatic species . . . . . . . . . . . . . . . . . . . . . . . . . . . 252

3.4. Funding opportunities for research training in aquatic animal health and pathology . . . . . . . . . . . . . . . . . . . . . 252

4. Proposal for an aquatic pathology center of expertise . . . . . . . . . . . . . . . . . . . . . . . . . . . 252

5. Mainstreaming peer review in aquatic pathology studies . . . . . . . . . . . . . . . . . . . . . . . . . . . . . . . . . . 252

6. Expanding reference resources and standardized diagnostic criteria for proliferative and nonproliferative lesions in key aquatic species . . . . . 253

6.1. Completion of an Atlas of Fish Tumors . . . . . . . . . . . . . . . . . . . . . . . . . . . 253

6.2. Current references on histology, histopathology, and systemic pathology of aquatic species . . . . . . . . . . . . . . . . . . . 253

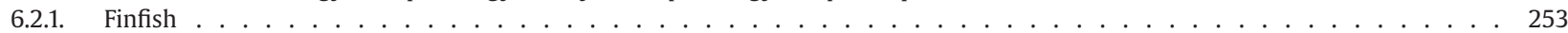

6.2.2. Invertebrates . . . . . . . . . . . . . . . . . . . . . . . . . . . . 254

6.3. Development of and facilitating access to standardized diagnostic criteria for proliferative and nonproliferative lesions in

key aquatic species. . . . . . . . . . . . . . . . . . . . . . . . . . . . . . . . 254

7. Educating the scientific community about the value of pathology . . . . . . . . . . . . . . . . . . . . . . . . . . 254

8. Defining the role of aquatic pathology in future risk assessments under the new partnership between the US National Institutes of

Health and the US Environmental Protection Agency emphasizing use of nonmammalian models . . . . . . . . . . . . . . . . . . 255

9. Need for additional support for shared resources and for basic and applied research in aquatic pathology $\quad \ldots \ldots \ldots$

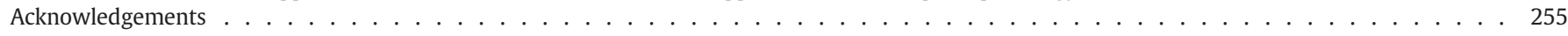

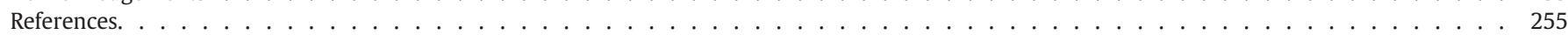

\section{Introduction}

Aquarium fish models are being utilized for biomedical research at an ever increasing rate. Publication of the sequences of the genomes for two of the major fish species used in research-the zebrafish, Danio rerio, and the medaka, Oryzias latipes,-has significantly enhanced their utility. Although long used for basic developmental biology (Kimmel, 1989; Grunwald and Eisen, 1999) and toxicology testing, the genome projects for these species allow more sophisticated studies of the molecular mechanisms of development, other biological phenomena, and disease. These advances allow small fish to be used globally in basic mechanistic research (Cheng, 2008). A subsequent explosion of interest arose worldwide in developing fish models for understanding basic vertebrate biological functions such as pigmentation (Lamason et al., 2005), pigment pattern formation (Quigley and Parichy, 2002), and a variety of human diseases (Amsterdam, 2006; Halpern, 2004; Henken et al., 2004; Hsu et al., 2007; Lieschke and Currie, 2007; Rasooly et al., 2003) including cancer (Kissling et al., 2006; Law, 2001; Merlino and Khanna, 2007; Moore et al., 2006; Stoletov and Klemke, 2008; Stoletov et al., 2007), Parkinson's disease (Panula et al., 2006; Wen et al., 2008), ocular pathology (Link et al., 2004; Soules and Link, 2005), hereditary renal disease (Hinkes et al., 2006; Mochizuki et al., 2005; Sullivan-Brown et al., 2008), fetal alcohol syndrome (Loucks et al., 2007; Wu et al., 2008), hereditary hematopoietic disorders (Carradice and Lieschke, 2008; Shafizadeh and Paw, 2004), and inherited degenerative muscle diseases (Steffen et al., 2007). Early life stages of aquarium fish can be raised in 96 or 384 well plates, with sorting of embryos, addition of reagents, and assessment of endpoints facilitated robotically, these models are now used as efficient and cost-effective tools for high-throughput drug discovery, safety testing, and hazard identification. Because they are whole vertebrate animals they have an advantage over simple cell cultures in allowing assessment of adsorption, distribution, metabolism and excretion of materials, as well as toxicity and dose-response for target tissues (Abbott et al., 2007; Kari et al., 2007; Lan et al., 2007; Zon and Peterson, 2005).

Nonmammalian aquatic species have filled a valuable role as sentinels reflecting environmental risks relevant to human health (Dawe et al., 1964). More recently, diverse nonmammalian aquatic species have been used increasingly to detect mutagens (Anderson and Wild, 1994; Geiger et al., 2006; Shima and Shimada, 1994), carcinogens (Couch and Harshbarger, 1985; Huff et al., 1991), and endocrine disruption worldwide (Blazer et al., 2007; Picard-Aitken et al., 2007; Wei et al., 2008).

Stewardship of resources of aquatic species globally has fallen short of maintaining sustainable populations of key species (Caddy and Seijo, 2005; Worm et al., 2006). As a result, aquaculture is playing a growing role in supplying finfish and shellfish for human consumption and to assist in restoration of depleted stocks of threatened and endangered aquatic species (Alves and Rosa, 2006; Cochrane and Doulman, 2005; Engelhaupt, 2007).

There is a critical shortage of highly trained comparative pathologists and toxicologic pathologists including those with expertise in aquatic species (Boorman, 2008; Cardiff et al., 2008; Cockerell and Patterson, 2005; Fox and Obernier, 2005). Thus concerted efforts are currently in process to recruit and train more comparative pathologists. The growing need for expertise in pathology of finfish and aquatic invertebrates is driven by the recent increased use and projected growth in use of these species in biomedical research, as environmental sentinels, and in aquaculture (Collins et al., 2008). Near coastal ecosystems as well as inland waters worldwide have experienced depletion of important commercial and noncommercial species associated with anthropogenic and nonanthropogenic effects (Chan et al., 2008; Ford and Smolowitz, 2007; Glenn and Pugh, 2006; Halpern et al., 2008; Lafferty et al., 2004). These aquatic species are essential for maintenance of ecosystem health, yet there are no organizations in North America or the world to coordinate funding for cooperation among stakeholders for training aquatic pathologists or for ensuring sharing of the collective expertise in aquatic pathology programs globally (Dewailly et al., 2002; Miller et al., 2005).

\section{Current training programs in aquatic pathology}

Educational programs in aquatic pathology with a focus on the diagnosis of disease based on the evaluation of gross and microscopic lesions in tissues and organs are not common in traditional veterinary anatomic pathology training programs. Where such pathology training programs exist today, they are primarily due to specific interest and expertise of individuals associated with those training 
programs. Should the individual with the motivation and interest move or retire, the training program may cease to exist.

\subsection{North American Veterinary Anatomic Pathology programs emphasizing aquatic pathology}

The Atlantic Veterinary College, University of Prince Edward Island The College of Veterinary Medicine, Cornell University

The College of Veterinary Medicine, University of Georgia

The College of Veterinary Medicine, North Carolina State University

The College of Veterinary Medicine, Mississippi State University

The Ontario Veterinary College, University of Guelph

The training in anatomic pathology of aquatic organisms at the above veterinary programs in several of the locations is a collaborative effort between faculty in veterinary pathology, aquatic health programs, diagnostic aquatic pathology, and other disciplines. Faculty may serve in multiple roles.

The Anatomic Pathology Training Program in the Department of Pathobiology and Veterinary Science at the University of Connecticut, Storrs, CT prepares veterinary pathologists for the American College of Veterinary Pathologists Anatomic Pathology certification exam. This training includes aquatic as well as terrestrial domestic and nondomestic species.

While the above discussion has focused on opportunities available in North America, the Institute of Aquaculture, University of Stirling, Scotland, UK, has a long history of providing educational opportunities in anatomic pathology of aquatic organisms.

\subsection{Short courses}

In addition to the above opportunities, several short-courses provide opportunities for training in anatomic pathology of aquatic organisms in North America. Some of these courses include:

\subsubsection{The AQUAVET Program}

The AQUAVET Program is a program in aquatic veterinary medicine that is jointly sponsored by the School of Veterinary Medicine of the University of Pennsylvania and the College of Veterinary Medicine at Cornell University. Courses have been offered at the Marine Biological Laboratory, Woods Hole, MA each spring since the mid-1970s (Aquavet I) and 1980s (Aquavet II). AQUAVET I-an introduction to aquatic veterinary medicine-is a 4 -week course that provides an overview to veterinary students with an interest in aquatic species. The course provides instruction over a wide diversity of topics, including anatomic pathology. AQUAVET II-comparative pathology of aquatic animals-is a 2-week advanced course. The course has a major focus on normal anatomy and pathology of aquatic invertebrates and fish that are of importance as biomedical research animals and as cultured species. A major portion of this course involves instruction in the identification of gross and microscopic lesions found in aquatic invertebrates and fish (http://www.aquavet.info/).

\subsubsection{Fish histology and histopathology}

This is a 5-day short-course offered at the National Conservation Training Center (NCTC), US FWS, Shepherdstown, WV. The course focuses on the identification of normal and abnormal microscopic anatomy of fish. While the course is offered primarily for employees of the US FWS, other interested individuals can apply for participation in the program. Instruction is offered by FWS and other specialists with expertise in histopathology of fish. Plans are underway to offer graduate credit for this course through West Virginia University (http://training.fws.gov/).

\subsubsection{Aquamed}

Aquamed-an aquatic animal pathobiology course-is offered by the Gulf States Consortium for Pathobiology. Aquamed is offered in even- numbered years. The objective of the course is to impart an understanding of health management techniques and pathological processes relating to the etiology, diagnosis, and treatment of important aquatic animal diseases. Aquamed is a 4-week educational opportunity. The course focuses on ornamental fish, cultured food fish and shellfish, but also has some coverage of aquatic mammals, reptiles, and aquatic laboratory animals. The course includes instruction in anatomic pathology (http://www.vetmed.lsu.edu/aquamed.htm).

\subsubsection{Shrimp Pathology Short Course: disease diagnosis and control in} marine shrimp culture

The Shrimp Pathology Short Course is offered annually by the University of Arizona. The course is a 2-week educational opportunity that has a focus on health management in marine shrimp aquaculture. The course provides instruction in anatomic pathology of the important diseases of shrimp (Lightner, 1996) (http://microvet.arizona.edu/ research/aquapath/2008\%20APL\%20Shortcourse\%20brochure.pdf).

\subsubsection{Health and colony management of laboratory fish}

The Health and Colony Management of Laboratory Fish course is a 1-week educational opportunity with the primary focus on minimizing the impact of disease in laboratory colonies of fish. The course is offered by the Mount Desert Island Biological Laboratory, Salisbury Cove, ME. While the course has a primary focus on zebrafish, it also covers other fish species. The course includes instruction in anatomic pathology of diseases in laboratory fish (http://www.mdibl.org/index. shtml).

\subsubsection{Envirovet}

The Envirovet Summer Institute is a 7-week, hands-on course focused on environmental influences on the health of terrestrial and aquatic species in North America and globally (http://www.cvm.uiuc. edu/envirovet/index.html). This program is coordinated by the College of Veterinary Medicine of the University of Illinois at ChampaignUrbana and orients students to basic concepts of ecology of infectious and noninfectious diseases, ecosystem health, conservation medicine, and the role of environmental changes in promoting zoonoses (Beasley, 1993; Gilardi et al., 2004). The course incorporates an international component, as well as sessions in Florida and Georgia, and has provided intensive training including histology, histopathology, and systemic pathology of terrestrial and aquatic wildlife to veterinarians, veterinary students, wildlife biologists, and other scientists for the past 17 years.

\subsubsection{The Canadian Aquaculture Institute (CAI)}

In conjunction with the Atlantic Veterinary College, the Canadian Aquaculture Institute at the University of Prince Edward Island, Canada, has offered a variety of short courses, as demand dictates, since 1994 (http://www.upei.ca/cai/about.html). These include courses in applied aquatic animal health and pathology of finfish and shellfish such as the most recently offered Mollusc Health and Disease Management which strongly emphasized mollusc histopathology.

\subsubsection{Advanced coral tissue slide reading workshop}

For 10 years a coral histology and histopathology workshop has been offered as one of Mote Marine Laboratory's advanced courses in Marine Sciences at its Tropical Research Laboratory, Summerland Key, FL. In 2008 the short course is held as part of the 11th International Coral Reef Symposium, Fort Lauderdale, FL (http://www.nova.edu/ ncri/11icrs/ancillary.html)

\subsubsection{Other universities offering courses in aquatic animal pathology or} histopathology of aquatic animals

The University of Miami, Virginia Institute of Marine Science, University of Washington and George Mason University offer courses in aquatic animal pathology. 


\section{Enhancing training programs in aquatic pathology}

The shortage of anatomic pathologists with expertise in aquatic species affects the quality of data generated in basic research, field epidemiology, and study of diseases in aquaculture. For example, Cardiff et al. (2008) have highlighted the compromises in the integrity of much research data regarding mutant rodent models due to the shortage of highly trained anatomic pathologists and consequent omission of proper oversight of this aspect of the research.

\subsection{Additional pathology residency programs with training in aquatic species}

Oregon State University is beginning Anatomic Veterinary Pathology and Veterinary Clinical Pathology programs that will include training in aquatic species. Oregon State University has long maintained a strong research program in diseases of aquatic animals, which includes affiliation and research collaboration with the Oregon Department of Fish and Wildlife, Hatfield Marine Science Center, Oregon Coast Aquarium, National Marine Fisheries Service (NOAA Fisheries Service), and the Aquarium Science Program at the Oregon Coast Community College. Now that Oregon State University's College of Veterinary Medicine has expanded to include the full services of a small animal clinic, the training programs in Veterinary Pathology are expanding in concert.

3.2. Enhancing training in histology, histopathology, and systemic pathology of aquatic species for biomedical scientists without professional clinical medical training

Diverse broad training and approaches in aquatic pathology strengthen research in this field. However, methods must be developed to ensure a basic level of competency in anatomic pathology among scientists working in this discipline. Graduate students completing Ph.D. training programs with an emphasis on pathology of aquatic species should be encouraged to obtain rigorous, comprehensive training in histology, histopathology, and systemic pathology of mammals and aquatic species. To be competent independent investigators focusing on aquatic pathology, they must gain training in morphologic pathology of aquatic species comparable to that obtained in a 3-year residency training program for veterinary pathologists or M.D. pathologists. Most veterinary colleges and medical schools allow Ph.D. students and biomedical scientists without medical backgrounds to attend their histology, histopathology and systemic pathology courses. Scientists from all backgrounds are welcome to attend short courses in Comparative Pathology and Pathology of Laboratory Animals sponsored by the Armed Forces Institute of Pathology and Charles Lewis Davis Foundation.

Currently the American Association for Cancer Research provides a short course titled Pathobiology of Cancer: the Edward A. Smuckler Memorial Workshop, a week-long course focusing on molecular and morphologic aspects of human cancer and its rodent model systems (http://www.aacr.org/page5414.aspx; http://www.aacr.org/Uploads/ DocumentRepository/Edu_Mtgs_Wrkshops/patho08_brochure.pdf). A similar short course focused on aquatic models for cancer research would be a valuable addition to the resources available for scientists training for careers using aquatic models for cancer research.

\subsection{Need for specific training in toxicologic pathology of aquatic species}

Although a number of training opportunities are available for learning about management of clinical diseases and diagnostic pathology of aquatic species, there are not yet any programs focused on teaching toxicologic pathology of aquatic species. Given the growing use of aquatic species in toxicology research and in environmental monitoring, short courses in aquatic toxicologic pathology are critically needed.
3.4. Funding opportunities for research training in aquatic animal health and pathology

The National Center for Research Resources provides funding opportunities that will support research training for veterinarians, M.D.s, and nonveterinarians interested in aquatic animal pathology. The T32 mechanism will fund institutional predoctoral and postdoctoral programs for nonmedical scientists, veterinarians, M.D.s and other medical scientists. The F31 and F32 funding mechanisms fund individual predoctoral and postdoctoral research training, respectively, for scientists from diverse backgrounds to train in biomedical sciences. K01 and K99/R00 funding programs are designed to foster establishment of independent research careers of biomedical scientists. Although currently the K26 awards are limited to Midcareer Mouse Pathobiology career enhancement for pathobiologists, expansion of the K26 to include aquatic animals seems justified based on the increasing use of these species in biomedical research.

A number of federal agencies including the U.S. Department of Agriculture, National Science Foundation, and the National Oceanic and Atmospheric Administration, including its Sea Grant program fund training of Ph.D. and post-doctoral fellows in aquatic animal pathology as part of the funding of research grants. The recently established joint NIH-NSF program to fund research on ecology of human and animal diseases should provide opportunities for training of scientists in aquatic animal pathology.

\section{Proposal for an aquatic pathology center of expertise}

We propose establishing an Aquatic Pathology Center of Expertise (APCE) to facilitate close collaboration between aquatic pathologists working in academia, industry and government. This center will act as a clearinghouse for discussion of controversial lesions in the various organ systems of key aquatic species, archive and disseminate information and high-quality images regarding morphologic diagnosis of lesions, coordinate pathology working groups to establish standardized diagnostic criteria for lesions of major organs and tissues of aquatic species, and aid in information sharing. This center will support educational programs training students in histology, histopathology, and systemic pathology of aquatic animals. In addition to formal residency and graduate programs offering training in aquatic pathology, this APCE will offer pathology residents and qualified graduate students an opportunity to rotate through training programs associated with the center that will offer exposure to a greater variety of case material and expertise than any individual program can provide. Considering the growing recognition of the close association between animal health and human health epitomized by the recent One Health Initiative established by the American Medical Association and the American Veterinary Medical Association (Cardiff et al., 2008), perhaps a cooperative funding program between the U.S. Centers for Disease Control, the U.S. National Institutes of Health, and the National Science Foundation would be appropriate. In Canada, the Department of Fisheries and Oceans, Environment Canada, and the Canadian Food Inspection Agency are possible sources of funding for this proposed center. The APCE will be most valuable to all sectors of society if both commercially important and noncommercial aquatic species that act as environmental sentinels are included. The center will act as an archive for the valuable case material from several aquatic pathologists who have retired or plan to retire.

\section{Mainstreaming peer review in aquatic pathology studies}

Most senior aquatic pathologists have encountered unnerving errors and/or misinterpretations of anatomy, histology and/or histopathology in photographs from submitted or published manuscripts (Cardiff et al., 2008). Despite such indications of inadequate training of scientists in aquatic animal anatomy, histology, and systemic pathology, 
an erosion of funding for aquatic pathology resources has occurred during recent years. Funding for the Registry of Tumors in Lower Animals (RTLA; http://www.pathology-registry.org/index_1.asp) was discontinued in September of 2007, after uninterrupted funding by the US National Cancer Institute since 1966. The RTLA served as a valuable resource for aquatic pathologists worldwide. The loss of this resource is a concern to all aquatic pathologists that we consulted. Well-equipped and respected aquatic pathology laboratories at the US Environmental Protection Agency Laboratories in Pensacola, Florida, and Narragansett, Rhode Island have been phased out. While modern pathologists are excited about the power to answer sophisticated questions using the "omics," we need to maintain strong funding and expertise for phenotype anchoring to complement the detailed molecular data. Gene expression studies on tissues of toxicant-treated fish are compromised when research animals have severe systemic mycobacteriosis, or other bacterial, viral, or parasite-induced inflammation in target tissues. Recent data confirm that inflammation of one tissue often profoundly affects signaling pathways in other tissues also (Kent et al., 2009-this issue; Stentiford et al., 2005).

The US National Toxicology Program in the National Institute of Environmental Health Sciences utilizes a standard protocol for evaluation of toxicants in rodent bioassays. These protocols utilize pathology peer review as a routine and regular part of the evaluation process. A necessary feature of efforts toward standardization of nomenclature and diagnostic criteria are the convening of pathology working groups as part of the quality assurance process to confirm standard evaluation of lesions and to resolve controversies in diagnosis and interpretation. A critical feature of and rationale for routine pathology peer review is to establish and maintain a standard system of description and nomenclature for lesion diagnosis. This standardization enables greater consistency in study evaluation and interpretation. The Society of Toxicologic Pathology (STP) has developed recommendations for the conduct of pathology peer review (http:// www.toxpath.org/Position_Papers/Peer_Review.pdf) as well as preparing best practices guidelines for conducting toxicologic histopathology, and for assessing lesions in specific organ systems. These guidelines as well as manuscripts older than 1 year from the STPsponsored journal Toxicologic Pathology are provided free as PDF files on the STP (http://www.toxpath.org) website.

Adapting the best practices guidelines for conduct of histopathology in rodents for use with aquatic species will result in consistent evaluation of studies using aquatic species and allow mainstreaming of aquatic animal studies to be incorporated into hazard identification, safety, and risk assessment. The proposed Aquatic Pathology Center of Expertise could facilitate preparation of these best practices guidelines through a pathology working group process to develop standard systems of nomenclature and diagnostic criteria (SSNDC).

\section{Expanding reference resources and standardized diagnostic criteria for proliferative and nonproliferative lesions in key aquatic species}

Much work remains to bring the pathology reference material available for finfish and invertebrates up to the standards of the reference material available for mammalian laboratory animals and humans. Substantial long-term funding and manpower will be required to ensure meeting the goals that we outline below.

\subsection{Completion of an Atlas of Fish Tumors}

A comprehensive organ system-based Atlas of Fish Tumors is in its initial draft with extensive illustrations, but languished following the untimely death of Dr. Clyde Dawe, who initiated the atlas. Dr. Dawe was the visionary M.D. comparative pathologist from the National Cancer Institute who instigated formation and continuance of the Registry of Tumors in Lower Animals. Scientists from around the world express a strong need for a comprehensive and up-to-date Atlas of Fish Tumors. A first step would be to complete and publish the Atlas of Fish Tumors. This could be a first step toward developing an SSNDC for common lesions in aquatic species used in aquaculture, research, and toxicant evaluation.

\subsection{Current references on histology, histopathology, and systemic pathology of aquatic species}

\subsubsection{Finfish}

A number of excellent references are available on the general topic of fish anatomy (Harder, 1975; Stoskopf, 1993), histology (Ashley, 1975; Chiasson, 1980; Fremling, 1978; Grizzle, 1978; Grizzle and Rogers, 1976; Groman, 1982; Morrison, 1987, 1988, 1990, 1993; Smith and Bell, 1976; Takashima and Hibiya, 1995; Willemse, 1979; Yasutake and Wales, 1983), histopathology, and systemic pathology (Ferguson, 2006; Hinton, 1997; Jagoe, 1996; Roberts, 2001). However, since fish are the most diverse group of vertebrate species, each individual species has unique anatomic and histologic features. Atlases of anatomy and histology are available for certain of the fish species used commonly in aquaculture and toxicity testing. Readers must use their personal judgement in evaluating the accuracy of the web-based anatomy, histology and histopathology information available, because most of these websites have not been subjected to rigorous peer review. A web-based Atlas of Fathead Minnow Normal Histology is provided by the University of Maryland Aquatic Pathobiology Center (http://aquaticpath.umd.edu/fhm). Despite the growth in the use of fish like zebrafish and medaka in research and toxicity and safety testing, the resources for standardizing anatomy, histology, and histopathology have not kept pace with the increased use or to achieve comparability with mammalian models (Spitsbergen and Kent, 2003).

Reference books on zebrafish anatomy and histology are available only for the adult (Wullimann et al., 1996) and developing brain (Mueller and Wullimann, 2005). In association with a genetic screen for histological mutants (Mohideen et al., 2003; Sabaliauskas et al., 2006; Tsao-Wu et al., 1998), higher throughput methods for early life stage histology, and a web-based atlas of zebrafish microanatomy throughout its lifespan is established (Cheng, 2004; http://zfatlas.psu. edu). Mechanisms for remote labeling by experts, inclusion of abnormalities (mutants, genetic knock-downs, and pathology), addition of 3D pathology and increasing integrations with ZFIN are being established. This atlas and the tools developed for it such as a comparison tool, ability to send links to specific fields from others, and customized molds for specimen orientation, will comprise a technological foundation for the study of mutants, toxicant effects, and pathology. Future plans for the zebrafish atlas include incorporation of tools for learning histology and pathology. Recent cutting edge imaging techniques including optical projection tomography (Bryson-Richardson and Currie, 2004; http://www.fishnet.org.au/FishNet/index.cfm), microcomputerized axial tomography (Vasquez et al., 2008; http:// numirabio.com/zebrafishGallery.html), micromagnetic resonance imaging, and high-frequency ultrasound have allowed detailed visualization of fine anatomic detail in normal and abnormal developing and adult zebrafish (Spitsbergen, 2007). Websites are developing to provide information regarding medaka anatomy (http://www.obofoundry. org/cgi-bin/detail.cgi?id=medaka_anatomy_development) and histology (http://www.env.go.jp/chemi/end/medaka.html). Brant Weinstein of the National Institute of Child Health and Human Development, USA, maintains a web-based atlas of the developing vascular system in zebrafish (http://zfish.nichd.nih.gov/zfatlas/Intro\%20Page/intro1. html). As part of the health monitoring services of the Zebrafish International Resource Center, USA, a website provides information and images of gross and microscopic lesions of the common infectious and noninfectious diseases of zebrafish (http://zebrafish.org/zirc/ health/diseaseManual.php). Leo van der Ven and Piet Wester of the 
Laboratory of Pathology and Immunobiology, National Institute of Public Health and the Environment, the Netherlands have developed a website showing normal and abnormal organ histology relevant to endocrine disruption in zebrafish by environmental contaminants (http://www.rivm.nl/fishtoxpat/). Coordination of these activities is an important goal and a growing challenge.

Those of us who have taught short courses regarding aquarium fish anatomy, histology, histopathology, and neoplasia, and those who have lectured on these topics abroad or lectured in North America or abroad on the use of the zebrafish model for study of human diseases like cancer, realize that there is a huge demand for detailed information in these areas by scientists from laboratory technicians, graduate students, post-doctoral fellows, laboratory animal veterinarians, veterinary pathologists, to biomedical scientists who serve as principal investigators on research projects using aquatic species.

The data regarding mutant lines of rodents clearly indicates that genetic background can influence the phenotype of lines with mutant genes, including factors such as susceptibility to specific infectious agents, response to carcinogens or other toxicants, and precise characteristics of innate and acquired immune responses (Begley et al., 2007; Brayton et al., 2001; Schofield et al., 2004; Sundberg et al., 1997). Recent data regarding zebrafish show that, as with rodents, genetic background can strongly influence the phenotype caused by a mutant gene, can influence susceptibility to noninfectious and infectious diseases as well as response to toxicants, and can affect characteristics of behavior (Dlugos and Rabin, 2003; Link et al., 2004; Loucks and Carvan, 2004; Sanders and Whitlock, 2003; Spitsbergen and Kent, 2003; Spitsbergen et al., 2002, 2004; Wright et al., 2006). Given the thousands of mutant lines of zebrafish and medaka in different genetic backgrounds, much work will be required to carefully phenotype each specific line in terms of normal anatomy, histology, clinical pathology and hematology parameters, and response to environmental agents or experimental treatments.

Aquatic pathologists would be wise to pattern the nomenclature of strains and mutant lines based on established protocols for rodents (http://www.informatics.jax.org/mgihome/nomen/strains.shtml). The laboratory source of the wild-type background strains needs to be indicated for mutant lines. A number of wild-type lines of zebrafish are used as background strains in which mutant genes and transgenes are propagated (http://zfin.org/cgi-bin/webdriver?MIval=aa-wtlist. apg). Also, the Tupfel long fin leopard line (Tuebingen long fin; TL), actually a compound mutant line, is often used as the genetic background for propagating mutant lines due to the greater hardiness and fecundity of this line compared to some of the wild-type lines. To fully understand the significance of an inactivated gene or a transgene, we will need to study that modified gene in multiple genetic backgrounds and document the phenotype using histological techniques and careful interpretation.

\subsubsection{Invertebrates}

Because invertebrates are even more diverse on a phylogenetic scale than fish, this situation creates a great challenge to pathologists in establishing expertise encompassing all species of aquatic invertebrates including those studied for commercial and noncommercial purposes. Invertebrate pathologists have concentrated more on etiologic agents and the use of these species as environmental sentinels than on systemic pathology and establishing standardized diagnostic criteria for comprehensive histologic assessment of tissues. As with finfish, both textbooks and internet resources are available with detailed information on anatomy and histology of selected aquatic invertebrate species, particularly those commercially harvested or used in aquaculture (Bell and Lightner, 1988; Bower and Blackbourn, 2003; Brusca et al., 2003; Factor, 1995; Johnson, 1980; Johnson and Otto, 1981; Kennedy et al., 1996; Kraeuter and Castagna, 2001; Shumway and Parsons, 2006). Harrison, together with various collaborators, has edited 15 volumes on the anatomy of invertebrates from protozoa to hemichordates, only a few of which we cite here (Harrison and Humes, 1992; Harrison and Kohn, 1994; Harrison and Ruppert, 1990). Textbooks and bibliographies regarding invertebrate pathology include Johnson (1968), Lewbart (2006), Pauley (1974), Sindermann (1990) and Sparks (1985). Because noncommercial species like corals are important sentinels indicating environmental degradation such as that related to global climate change, information on these species is essential also (Couch and Fournie, 1992; Fisher, 1988; Galloway et al., 2007; Jangoux 1987a,b,c; Kinne 1980, 1984; Patterson et al., 2002; Peters, 1993; Peters et al., 2005; Rosenberg and Loya, 2004; Sandin et al., 2008). Websites with anatomy, histology, and disease information regarding aquatic invertebrates include http:// library.enaca.org/NACA-Publications/ADG-CrustaceanDiseases.pdf, http://www.lobsterscience.ca/articles/fact/bumpercar.pdf, http://www. mainefishermensforum.org/Recaps2005/Lobster\%20Disease/Lobster\% 20Disease.htm, http://www.dmoz.org/Science/Biology/Flora_and_Fauna/ Animalia/Mollusca/Bivalvia/, and http://www.vims.edu/tcs/Atlas\%20of\% 20Lobster\%20Anatomy_files/frame.htm.

6.3. Development of and facilitating access to standardized diagnostic criteria for proliferative and nonproliferative lesions in key aquatic species

As the sophistication of toxicologic pathology and risk assessment increased in North America and worldwide, members of the Society of Toxicologic Pathology (STP) and comparable organizations around the world realized that a System of Standardized Nomenclature and Diagnostic Criteria (SSNDC) for proliferative and nonproliferative lesions in major organ systems of research animals would assist in consistent evaluation of tissues in safety assessments as well as in basic research, and would greatly facilitate pathology peer review. Working groups were organized by the STP, and detailed guides illustrated with high-quality color illustrations were published with cooperation between the STP and the American Registry of Pathology (ARP) of the Armed Forces Institute of Pathology (AFIP). These guides were produced first for the rat, then for the mouse from 1990 up until the present time. These guides are now available as PDF files free to the public on the STP website (http://www.toxpath.org/ssndc.asp). A series of books on Histological Classification Tumors of Domestic Animals was published in the late 1990s as a cooperative effort between the ARP of the AFIP and the World Health Organization Collaborating Center for Worldwide Reference on Comparative Oncology. In the mid to late 1990s, the International Agency for Research on Cancer, a branch of the World Health Organization, published a series of books on the International Classification of Rodent Tumors. These guides provide a model for the development of SSNDC for proliferative and nonproliferative lesions in key aquatic species.

To date, a few publications are available providing carefully described and extensively illustrated diagnostic criteria for lesions in specific organs such as liver for a very few finfish species (Blazer et al., 2006; Boorman et al., 1997), or for selected organs such as thyroid in finfish in general (Fournie et al., 2005). The Registry of Tumors in Lower Animals was instituting a system for SSNDC for the cases that it posted on its website.

\section{Educating the scientific community about the value of pathology}

Because aquatic pathology is critical for conduct of the best basic research, environmental monitoring, and aquaculture disease research, it is essential that morphologic pathology be valued, funded, and rewarded with career advancement equally to other disciplines such as genetics, cell biology, molecular biology and immunology. This has not been the case in North America over the past 2 decades. To design and conduct the highest quality research, properly trained aquatic pathologists must be integrally involved in experimental design, trouble-shooting during the conduct of the experiment, data analysis, and data interpretation. Morphologic pathology should not be 
considered an add-on, after all other essential research components are planned. Recruitment of the brightest young minds to aquatic pathology will be possible only if the respect, career advancement, and funding of scientists specializing in morphologic pathology is comparable to the treatment of scientists who study other disciplines using aquatic species. Young scientists should be free to choose careers emphasizing diagnostic aquatic pathology or basic aquatic pathology research, regardless of their primary training as veterinarians, medical doctors, or Ph.D. biomedical scientists and pathobiologists. It is counterproductive to recruitment to stereotype morphologic pathologists as service staff if their career goal and career training have been to pursue basic research. If we invest the resources to train young scientists in anatomic pathology combined with cutting edge molecular pathology, we must create positions in which these scientists can engage in independent basic research. In today's funding environment, it is not realistic to balance a substantial diagnostic service commitment with competitive basic research activities. Veterinary diagnostic laboratories are already short staffed and under funded to provide service for laboratory, pet, and food animal species. Additional funding and programs are required to provide the necessary staffing and expertise to provide high-quality diagnostic and basic research resources in aquatic pathology. Aquatic pathologists must take advantage of every opportunity to engage in outreach to and collaboration with other disciplines in order to increase appreciation of the essential role of anatomic pathology in high-quality aquaculture, basic research, and environmental monitoring.

\section{Defining the role of aquatic pathology in future risk assessments under the new partnership between the US National Institutes of Health and the US Environmental Protection Agency emphasizing use of nonmammalian models}

Recent reports by the National Research Council Committee on Toxicity Testing and Assessment of Environmental Agents suggested a major shift in the approach for evaluating risks from environmental agents. In response to these suggestions the US Environmental Protection Agency in partnership with the National Institutes of Health is developing a strategic plan that emphasizes computational toxicology, biochemical and cell-based in vitro assays, and greater use of alternative animal models (Collins et al., 2008). This increased emphasis on nonmammalian models is likely to increase the use of aquatic species in risk assessment, further highlighting the need to ensure a strong, optimally trained workforce in aquatic pathology that will use a standard approach in lesion diagnosis.

The European Union has recently instituted the REACH program (Registration, Evaluation, and Authorization of Chemicals) that emphasizes computer-based structure-activity modeling and greater use of fish in risk assessment of environmental materials (Foth and Hayes, 2008). This greater emphasis on fish for toxicity testing in the European Union will also increase the need for expertise in aquatic pathology.

Anatomic pathology also is an important component in ecological risk assessment, considering physical and biological stressors, as well as chemical contaminants (USEPA, 1992). Ecologists, environmental consultants, and regulatory organizations at all levels must be educated regarding the value of anatomic pathology in holistic risk assessment.

\section{Need for additional support for shared resources and for basic and applied research in aquatic pathology}

To develop the pathology database so that key aquatic species used as models in basic research, as sentinels for environmental monitoring, in commercial or restoration aquaculture, and in toxicity testing can be best utilized with the greatest sophistication, more support must be allocated to provide appropriately trained pathologists that can accurately interpret lesions in aquatic species. Such an effort will require substantial dedicated and continuing funding. Ideally this enhanced database on morphologic pathology of aquatic species will be integrated with the current existing databases such as the ZFIN database managed by the Zebrafish International Resource Center (Sprague et al., 2008; http://zfin.org/cgi-bin/webdriver?MIval=aaZDB_home.apg) and the Comparative Toxicogenomics Database developed for aquatic species by the Mount Desert Island Biological Laboratory (http://www.mdibl.org/research/ctd.shtml). We envision user-friendly web-based access to the integrated database of aquatic morphologic pathology interfaced with the sophisticated databases on genetics, genomics, proteomics, and metabolomics of key aquatic species. Organizations that may contribute support for the training and resources needed to bring aquatic animal pathology into parity with mammalian pathology include the World Health Organization and its International Agency for Research on Cancer, the International Life Sciences Institute (ILSI), the American Registry of Pathology of the Armed Forces Institute of Pathology, the Bill and Melinda Gates Foundation, and the Howard Hughes Medical Institute. Recently the National Science Foundation and the National Institutes of Health have partnered to fund studies of the ecology of disease to address influences of environmental alterations such as global warming and habitat degradation on animal and human diseases (http://nsf.gov/ funding/pgm_summ.jsp?pims_id=5269). Joint NSF-NIH programs such as this can contribute to the advancement of the field of aquatic pathology. Professional societies such as the American College of Veterinary Pathologists, the Society of Toxicologic Pathology, and American Society for Investigative Pathology can assist in educating their members regarding the need for training and expertise in aquatic pathology by hosting more frequent symposia on this topic, and by designating committees to encourage progress toward our goals. We welcome input from the scientific community regarding their needs and priorities in aquatic pathology. We encourage suggestions and guidance to develop our proposed Aquatic Pathology Center of Expertise.

\section{Acknowledgements}

We appreciate the administrative support from the Department of Microbiology, host of the Center for Fish Disease Research at Oregon State University. Facilities supporting aquatic pathology activities of J.M.S. include U.S. Public Health Service Grants ES03850 and ES00210 from the National Institutes of Environmental Health Sciences, RR12546 from the National Center for Research Resources, and the John Fryer Salmon Disease Laboratory at Oregon State University. Development of the webbased atlas of zebrafish anatomy and histology is supported by RR017441 from the National Center for Research Resources, Pennsylvania Tobacco Funds, and the Jake Gittlen Memorial Golf Tournament to K.C.C.

\section{References}

Abbott, D.E., Postovit, L.M., Seftor, E.A., Margaryan, N.V., Seftor, R.E., Hendrix, M.J., 2007. Exploiting the convergence of embryonic and tumorigenic signaling pathways to develop new therapeutic targets. Stem Cell Rev. 3, 68-78.

Alves, R.R., Rosa, I.L., 2006. From cnidarians to mammals: the use of animals as remedies in fishing communities in NE Brazil. J. Ethnopharmacol. 107, 259-276.

Amsterdam, A., 2006. Insertional mutagenesis in zebrafish: genes for development, genes for disease. Brief. Funct. Genomic Proteomic 5, 19-23.

Anderson, S.L., Wild, G.C., 1994. Linking genotoxic responses and reproductive success in ecotoxicology. Environ. Health Perspect. 102, 9-12 Suppl 12.

Ashley, L.M., 1975. Comparative fish histology. In: Ribelin, W.E., Migaki, G. (Eds.), The Pathology of Fishes. University of Wisconsin Press, Madison, WI, pp. 3-30.

Beasley, V., 1993. Ecotoxicology and ecosystem health: roles for veterinarians; goals of the Envirovet program. J. Am. Vet. Med. Assoc. 203, 617-628.

Begley, D.A., Krupke, D.M., Vincent, M.J., Sundberg, J.P., Bult, C.J., Eppig, J.T., 2007. Mouse Tumor Biology Database (MTB): status update and future directions. Nucleic Acids Res. 35, D638-D642.

Bell, T.A., Lightner, D.V., 1988. Handbook of Normal Penaeid Shrimp Histology. World Aquaculture Society, Baton Rouge, LA.

Blazer, V.S., Fournie, J.W., Wolf, J.C., Wolfe, M.J., 2006. Diagnostic criteria for proliferative hepatic lesions in brown bullhead Ameiurus nebulosus. Dis. Aquat. Org. 72, 19-30.

Blazer, V.S., Iwanowicz, L.R., Iwanowicz, D.D., Smith, D.R., Young, J.A., Hedrick, J.D., Foster, S.W., Reeser, S.J., 2007. Intersex (testicular oocytes) in smallmouth bass from 
the Potomac River and selected nearby drainages. J. Aquat. Anim. Health 19, 242-253.

Brayton, C., Justice, M., Montgomery, C.A., 2001. Evaluating mutant mice: anatomic pathology. Vet. Pathol. 38, 1-19.

Boorman, G.A., 2008. How do we create and maintain toxicologic pathologists? Scope, Newsl. Soc. Toxicol. Pathol. 26, 1-3.

Boorman, G.A., Botts, S., Bunton, T.E., Fournie, J.W., Harshbarger, J.C., Hawkins, W.E., Hinton, D.E., Jokinen, M.P., Okihiro, M.S., Wolfe, M.J., 1997. Diagnostic criteria for degenerative, inflammatory, proliferative nonneoplastic and neoplastic liver lesions in medaka (Oryzias latipes): consensus of a National Toxicology Program Pathology Working Group. Toxicol. Pathol. 25, 202-210.

Bower, S.M., Blackbourn, J., 2003. Geoduck Clam (Panopea abrupta): Anatomy, Histology, Development, Pathology, Parasites and Symbionts. Fisheries and Oceans, Canada Ottawa, Canada.

Brusca, R.C., Brusca, G.J., Haver, N.J., 2003. Invertebrates. Sinauer Associates, Sunderland, MA.

Bryson-Richardson, R.J., Currie, P.D., 2004. Optical projection tomography for spatiotemporal analysis in the zebrafish. Methods Cell Biol. 76, 37-50.

Caddy, J.F., Seijo, J.C., 2005. This is more difficult than we thought! The responsibility of scientists, managers and stakeholders to mitigate the unsustainability of marine fisheries. Philos. Trans. R. Soc. Lond., B Biol. Sci. 360, 59-75.

Cardiff, R.D., Ward, J.M., Barthold, S.W., 2008. 'One medicine-one pathology:' are veterinary and human pathology prepared? Lab. Invest. 88, 18-26.

Carradice, D., Lieschke, G.J., 2008. Zebrafish in hematology: sushi or science? Blood 111, 3331-3342.

Chan, F., Barth, J.A., Lubchenco, J., Kirincich, A., Weeks, H., Peterson, W.T., Menge, B.A., 2008. Emergence of anoxia in the California current large marine ecosystem. Science 319, 920.

Cheng, K.C., 2004. A life-span atlas for the zebrafish. Zebrafish 1, 69.

Cheng, K.C., 2008. Views on four key questions about zebrafish research. Zebrafish 5, 9-24.

Chiasson, R.B., 1980. Laboratory Anatomy of the Perch, 3rd ed. W. C. Brown Co. Publishers, Dubuque, Iowa.

Cochrane, K.L., Doulman, D.J., 2005. The rising tide of fisheries instruments and the struggle to keep afloat. Philos. Trans. R. Soc. Lond., B Biol. Sci. 360, 77-94.

Cockerell, G.L., Patterson, D.R., 2005. Closing the supply vs. demand gap for veterinary pathologists: a multifaceted problem in need of a multifaceted solution. Vet. Pathol. 42, 403-404.

Collins, F.S., Gray, G.M., Bucher, J.R., 2008. Toxicology. Transforming environmental health protection. Science 319, 906-907.

Couch, J.A., Harshbarger, J.C., 1985. Effects of carcinogenic agents on aquatic animals: an environmental and experimental overview. Environ. Carcinog. Rev. 3, 63-105.

Couch, J.A., Fournie, J.W., 1992. Pathobiology of Marine and Estuarine Organisms. CRC Press, Boca Raton, Florida.

Dawe, C.J., Stanton, M.F., Schwartz, F.J., 1964. Hepatic neoplasms in native bottomfeeding fish of Deep Creek Lake, Maryland. Cancer Res. 24, 1194-1201.

Dewailly, E., Furgal, C., Knap, A., Galvin, J., Baden, D., Bowen, B., Depledge, M., Duguay, L., Fleming, L., Ford, T., Moser, F., Owen, R., Suk, W.A., Unluata, U., 2002. Indicators of ocean and human health. Can. J. Public Health. Revue Canadienne de Sante Publique 93, S34-38.

Dlugos, C.A., Rabin, R.A., 2003. Ethanol effects on three strains of zebrafish: model system for genetic investigations. Pharmacol. Biochem. Behav. 74, 471-480.

Engelhaupt, E., 2007. Farming the deep blue sea. Environ. Sci. Technol. 41, 4188-4191.

Factor, J.R., 1995. Biology of the Lobster, Homarus americanus. Academic Press, San Diego, CA.

Ferguson, H.W., 2006. Systemic Pathology of Fish: A Text and Atlas of Normal Tissues in Teleosts and Their Responses to Disease, 2nd ed. Scotian Press, London.

Fisher, W.S., 1988. Disease Processes in Marine Bivalve Molluscs. American Fisheries Society, Bethesda, Maryland.

Ford, S.E., Smolowitz, R., 2007. Infection dynamics of an oyster parasite in its newly expanded range. Mar. Biol. 151, 119-133.

Foth, H., Hayes, A., 2008. Concept of REACH and impact on evaluation of chemicals. Hum. Exp. Toxicol. 27, 5-21.

Fournie, J.W., Wolfe, M.J., Wolf, J.C., Courtney, L.A., Johnson, R.D., Hawkins, W.E., 2005. Diagnostic criteria for proliferative thyroid lesions in bony fishes. Toxicol. Pathol. $33,540-551$.

Fox, J.G., Obernier, J., 2005. Veterinarians in biomedical research: a perilous future? J. Vet. Med. Educ. 32, 301-305.

Fremling, C.R., 1978. Biology and Functional Anatomy of the Freshwater Drum Aplodinotus grunniens Rafinesque. NASCO, Fort Atkinson, Wisconsin.

Galloway, S.B., Work, T.M., Bochsler, V.S., Harley, R.A., Kramarsky-Winters, E., McLaughlin, S.M., Meteyer, C.U., Morado, J.F., Nicholson, J.H., Parnell, P.G., Peters, E.C., Reynolds, T.L., Rotstein, D.S., Sileo, L., Woodley, C.M., 2007. Coral disease and health workshop: coral histopathology II. NOAA Technical Memorandum, vol. 56 National Oceanic and Atmospheric Administration, Silver Spring, MD.

Geiger, G.A., Parker, S.E., Beothy, A.P., Tucker, J.A., Mullins, M.C., Kao, G.D., 2006. Zebrafish as a "biosensor"? Effects of ionizing radiation and amifostine on embryonic viability and development. Cancer Res. 66, 8172-8181.

Gilardi, K.V.K., Else, J.G., Beasley, V.R., 2004. Envirovet summer institute: integrating veterinary medicine into ecosystem health practice. EcoHealth 1, S50-S55.

Glenn, R.P., Pugh, T.L., 2006. Epizootic shell disease in American lobster (Homarus americanus) in Massachusetts coastal waters: interactions of temperature, maturity, and intermolt duration. J. Crustac. Biol. 26, 639-645.

Grizzle, J.M., 1978. Anatomy and Histology of the Golden Shiner and Fathead Minnow. Agricultural Experiment Station, Auburn University, Auburn, Alabama.

Grizzle, J.M., Rogers, W.A., 1976. Anatomy and Histology of the Channel Catfish. Agricultural Experiment Station, Auburn University, Auburn, Alabama.

Groman, D.B., 1982. Histology of the Striped Bass. American Fisheries Society, Bethesda, MD.
Grunwald, D.J., Eisen, J.S., 1999. Headwaters of the zebrafish-emergence of a new model vertebrate. Nat. Rev. Genet. 3, 717-724

Halpern, M., 2004. Special issue: medaka. Mech. Dev. 121.

Halpern, B.S., Walbridge, S., Selkoe, K.A., Kappel, C.V., Micheli, F., D'Agrosa, C., Bruno, J.F. Casey, K.S., Ebert, C., Fox, H.E., Fujita, R., Heinemann, D., Lenihan, H.S., Madin, E.M., Perry, M.T., Selig, E.R., Spalding, M., Steneck, R., Watson, R., 2008. A global map of human impact on marine ecosystems. Science 319, 948-952.

Harder, W., 1975. Anatomy of Fishes. E. Schweizerbart'sche Verlagsbuchhandlung (Nagele u. Obermiller), Stuttgart, West Germany.

Harrison, F.W., Ruppert, E.E., 1990. Microscopic Anatomy of Invertebrates. Vol. 2: Placozoa, Porifera, Cnidaria, and Ctenophora. Wiley-Liss, NY, NY.

Harrison, F.W., Humes, A.G., 1992. Microscopic Anatomy of Invertebrates, Vol. 10: Decapod Crustacea. Wiley-Liss, NY, NY.

Harrison, F.W., Kohn, A.J., 1994. Microscopic Anatomy of Invertebrates. Vol. 5: Mollusca I. Wiley-Liss, NY, NY.

Henken, D.B., Rasooly, R.S., Javois, L., Hewitt, A.T., 2004. The National Institutes of Health and the growth of the zebrafish as an experimental model organism. Zebrafish 1 105-110.

Hinkes, B., Wiggins, R.C., Gbadegesin, R., Vlangos, C.N., Seelow, D., Nurnberg, G., Garg, P. Verma, R., Chaib, H., Hoskins, B.E., Ashraf, S., Becker, C., Hennies, H.C., Goyal, M., Wharram, B.L., Schachter, A.D., Mudumana, S., Drummond, I., Kerjaschki, D. Waldherr, R., Dietrich, A., Ozaltin, F., Bakkaloglu, A., Cleper, R., Basel-Vanagaite, L. Pohl, M., Griebel, M., Tsygin, A.N., Soylu, A., Muller, D., Sorli, C.S., Bunney, T.D., Katan, M., Liu, J., Attanasio, M., O'Toole, J.F., Hasselbacher, K., Mucha, B., Otto, E.A., Airik, R. Kispert, A., Kelley, G.G., Smrcka, A.V., Gudermann, T., Holzman, L.B., Nurnberg, P., Hildebrandt, F., 2006. Positional cloning uncovers mutations in PLCE1 responsible for a nephrotic syndrome variant that may be reversible. Nat. Genet. 38, 1397-1405.

Hinton, D.E., 1997. Histologic responses signifying exposure or effect and their application to aquatic toxicology. In: Zelikoff, J.T., Lynch, J.M., Shepers, J. (Eds.) Ecotoxicology: Responses, Biomarkers, and Risk Assessment. Organization for Economic Cooperation and Development, Paris, France, pp. 293-309.

Hsu, C.H., Wen, Z.H., Lin, C.S., Chakraborty, C., 2007. The zebrafish model: use in studying cellular mechanisms for a spectrum of clinical disease entities. Curr. Neurovasc. Res. 4, 111-120.

Huff, J., Bucher, J., Yang, R., 1991. Carcinogenesis studies in rodents for evaluating risks associated with chemical carcinogens in aquatic food animals. Environ. Health Perspect. 90, 127-132.

Jagoe, C.H., 1996. Responses at the tissue level: quantitative methods in histopathology applied to ecotoxicology. In: Newman, M.C., Jagoe, C.H. (Eds.), Ecotoxicology: A Hierarchical Treatment. Lewis Publishers, Boca Raton, Florida, pp. 163-196.

Jangoux, M., 1987a. Diseases of echinodermata. 1. agents microorganisms and protistans. Dis. Aquat. Org. 2, 147-162.

Jangoux, M., 1987b. Diseases of echinodermata. 2. agents metazoans (mesozoa to bryozoa). Dis. Aquat. Org. 2, 205-234.

Jangoux, M., 1987c. Diseases of echinodermata. IV. structural abnormalities and general considerations on biotic diseases. Dis. Aquat. Org. 3, 221-229.

Johnson, P.T., 1968. An Annotated Bibliography of Pathology in Invertebrates other than Insects. Burgess Publishing Co., Minneapolis, Minnesota.

Johnson, P.T., 1980. Histology of the blue crab, Callinectes sapidus. A Model for the Decapoda. Praeger, NY, NY.

Johnson, P.T., Otto, S.V., 1981. Histology of a bilateral gynandromorph of the blue crab Callinectes sapidus rathbun (decapoda: portunidae). Biol. Bull. 161, 236-245.

Kari, G., Rodeck, U., Dicker, A.P., 2007. Zebrafish: an emerging model system for human disease and drug discovery. Clin. Pharmacol. Ther. 82, 70-80.

Kennedy, V.S., Newell, R.I.E., Eble, A.F., 1996. The Eastern Oyster: Crassostrea virginica University of Maryland Sea Grant Publications, College Park, MD.

Kent, M.L., Feist, S.W., Harper, C., Hoogstraten-Miller, S., Law, J.M., Sanchez-Morgado, J.M. Tanguay, R.L., Sanders, G.E., Spitsbergen, J.M., Whipps, C.M., 2009. Recommendations for control of pathogens and infectious diseases in fish research facilities. Comp. Biochem. Physiol. C 149, 240-248 (this issue). doi:10.1016/j. cbpc.2008.08.001.

Kimmel, C.B., 1989. Genetics and early development of zebrafish. Trends Genet. 5, 283-288

Kinne, O., 1980. Diseases of Marine Animals. Volume I. General Aspects, Protozoa to Gastropoda. John Wiley and Sons, NY, NY.

Kinne, O., 1984. Diseases of Marine Animals. Volume II. Bivalvia to Arthropoda. John Wiley and Sons, NY, NY.

Kissling, G.E., Bernheim, N.J., Hawkins, W.E., Wolfe, M.J., Jokinen, M.P., Smith, C.S., Herbert, R.A., Boorman, G.A., 2006. The utility of the guppy (Poecilia reticulata) and medaka (Oryzias latipes) in evaluation of chemicals for carcinogenicity. Toxicol. Sci. 92, 143-156.

Kraeuter, J.N., Castagna, M., 2001. Biology of the Hard Clam. Elsevier Science Amsterdam.

Lafferty, K.D., Porter, J.W., Ford, S.E., 2004. Are diseases increasing in the ocean? Annu. Rev. Ecol. Evol. Syst. 35, 31-54.

Lamason, R.L., Mohideen, M.A., Mest, J.R., Wong, A.C., Norton, H.L., Aros, M.C., Jurynec, M.J., Mao, X., Humphreville, V.R., Humbert, J.E., Sinha, S., Moore, J.L., Jagadeeswaran, P., Zhao, W., Ning, G., Makalowska, I., McKeigue, P.M., O'Donnell, D., Kittles, R., Parra, E.J., Mangini, N.J., Grunwald, D.J., Shriver, M.D., Canfield, V.A., Cheng, K.C., 2005 SLC24A5, a putative cation exchanger, affects pigmentation in zebrafish and humans. Science 310, 1782-1786.

Lan, C., Laurenson, S., Copp, B.R., Cattin, P.M., Love, D.R., 2007. Whole organism approaches to chemical genomics: the promising role of zebrafish (Danio rerio) Exp. Opin. Drug Discov. 2, 1389-1401.

Law, J.M., 2001. Mechanistic considerations in small fish carcinogenicity testing. Ilar J $42,274-284$.

Lewbart, G.A., 2006. Invertebrate Medicine. Blackwell Publishing Professional, Ames, Iowa. 
Lieschke, G.J., Currie, P.D., 2007. Animal models of human disease: zebrafish swim into view. Nat. Rev. Genet. 8, 353-367.

Lightner, D.V., 1996. Handbook of Shrimp Pathology and Diagnostic Procedures for Diseases of Cultured Penaeid Shrimp. World Aquaculture Society.

Link, B.A., Gray, M.P., Smith, R.S., John, S.W., 2004. Intraocular pressure in zebrafish: comparison of inbred strains and identification of a reduced melanin mutant with raised IOP. Invest. Ophthalmol. Vis. Sci. 45, 4415-4422.

Loucks, E., Carvan III, M.J., 2004. Strain-dependent effects of developmental ethanol exposure in zebrafish. Neurotoxicol. Teratol. 26, 745-755.

Loucks, E.J., Schwend, T., Ahlgren, S.C., 2007. Molecular changes associated with teratogen-induced cyclopia. Birth Defects Res. A Clin. Mol. Teratol. 79, 642-651.

Merlino, G., Khanna, C., 2007. Fishing for the origins of cancer. Genes Dev. 21, $1275-1279$.

Miller, W.A., Miller, M.A., Gardner, I.A., Atwill, E.R., Harris, M., Ames, J., Jessup, D., Melli, A., Paradies, D., Worcester, K., Olin, P., Barnes, N., Conrad, P.A., 2005. New genotypes and factors associated with cryptosporidium detection in mussels (Mytilus spp.) along the California coast. Int. J. Parasitol. 35, 1103-1113.

Mochizuki, E., Fukuta, K., Tada, T., Harada, T., Watanabe, N., Matsuo, S., Hashimoto, H. Ozato, K., Wakamatsu, Y., 2005. Fish mesonephric model of polycystic kidney disease in medaka (Oryzias latipes) pc mutant. Kidney Int. 68, 23-34

Mohideen, M.A., Beckwith, L.G., Tsao-Wu, G.S., Moore, J.L., Wong, A.C., Chinoy, M.R. Cheng, K.C., 2003. Histology-based screen for zebrafish mutants with abnormal cell differentiation. Dev. Dyn. 228, 414-423.

Moore, J.L., Rush, L.M., Breneman, C., Mohideen, M.A., Cheng, K.C., 2006. Zebrafish genomic instability mutants and cancer susceptibility. Genetics 174, 585-600.

Morrison, C.M., 1987. Histology of the Atlantic cod, Gadus morhua: an atlas. Part one. Digestive Tract and Associated Organs. Department of Fisheries and Oceans, Canada, Ottawa, Ontario, Canada.

Morrison, C.M., 1988. Histology of the Atlantic cod, Gadus morhua: an atlas. Part two. Respiratory System and Pseudobranch. Department of Fisheries and Oceans, Canada Ottawa, Ontario, Canada.

Morrison, C.M., 1990. Histology of the Atlantic cod, Gadus morhua: An atlas. Part three. Reproductive Tract. Department of Fisheries and Oceans, Canada, Ottawa, Ontario, Canada.

Morrison, C.M., 1993. Histology of the Atlantic Cod, Gadus morhua: an atlas. Part four. Eleutheroembryo and Larva. Department of Fisheries and Oceans, Canada, Ottawa, Ontario, Canada.

Mueller, T., Wullimann, M.F., 2005. Atlas of Early Zebrafish Brain Development. Elsevier St. Louis, Missouri.

Panula, P., Sallinen, V., Sundvik, M., Kolehmainen, J., Torkko, V., Tiittula, A., Moshnyakov, M., Podlasz, P., 2006. Modulatory neurotransmitter systems and behavior: towards zebrafish models of neurodegenerative diseases. Zebrafish 3, 235-247.

Patterson, K.L., Porter, J.W., Ritchie, K.B., Polson, S.W., Mueller, E., Peters, E.C., Santavy, D.L. Smith, G.W., 2002. The etiology of white pox, a lethal disease of the Caribbean elkhorn coral, Acropora palmata. Proc. Natl. Acad. Sci. U. S. A. 99, 8725-8730.

Pauley, G.B., 1974. A Bibliography of Pathology in Invertebrates other than Insects from 1969-1972. U.S. Department of Commerce, Middle Atlantic Coastal Fisheries Center, Oxford, Maryland.

Peters, E.C., 1993. Diseases of other invertebrate phyla: porifera, cnidaria, ctenophora, annelida, echinodermata. In: Couch, J.A., Fournie, J.W. (Eds.), Pathobiology of Marine and Estuarine Organisms. CRC Press, Boca Raton, FL, pp. 393-449.

Peters, E.C., Price, K.L., Borsay Horowitz, D.J., 2005. Histological preparation of invertebrates for evaluating contaminant effects. In: Ostrander, G.K. (Ed.), Techniques in Aquatic Toxicology, vol. 2. Taylor \& Francis, Boca Raton, Florida.

Picard-Aitken, M., Fournier, H., Pariseau, R., Marcogliese, D.J., Cyr, D.G., 2007. Thyroid disruption in walleye (Sander vitreus) exposed to environmental contaminants: cloning and use of iodothyronine deiodinases as molecular biomarkers. Aquat Toxicol. 83, 200-211.

Quigley, I.K., Parichy, D.M., 2002. Pigment pattern formation in zebrafish: a model for developmental genetics and the evolution of form. Microsc. Res. Tech. 58, 442-455.

Rasooly, R.S., Henken, D., Freeman, N., Tompkins, L., Badman, D., Briggs, J., Hewitt, A.T. 2003. Genetic and genomic tools for zebrafish research: the NIH zebrafish initiative. Dev. Dyn. 228, 490-496.

Roberts, R.J., 2001. Fish Pathology, 3rd ed. W.B Saunders, Philadelphia, PA.

Rosenberg, E., Loya, Y., 2004. Coral Health and Disease. Springer-Verlag, Berlin.

Sabaliauskas, N.A., Foutz, C.A., Mest, J.R., Budgeon, L.R., Sidor, A.T., Gershenson, J.A., Joshi, S.B., Cheng, K.C., 2006. High-throughput zebrafish histology. Methods 39, 246-254

Sanders, L.H., Whitlock, K.E., 2003. Phenotype of the zebrafish masterblind (mbl) mutant is dependent on genetic background. Dev. Dyn. 227, 291-300.

Sandin, S.A., Smith, J.E., Demartini, E.E., Dinsdale, E.A., Donner, S.D., Friedlander, A.M. Konotchick, T., Malay, M., Maragos, J.E., Obura, D., Pantos, O., Paulay, G., Richie, M. Rohwer, F., Schroeder, R.E., Walsh, S., Jackson, J.B., Knowlton, N., Sala, E., 2008. Baselines and degradation of coral reefs in the Northern Line Islands. PLoS ONE 3 , e1548.

Schofield, P.N., Bard, J.B., Booth, C., Boniver, J., Covelli, V., Delvenne, P., Ellender, M., Engstrom, W., Goessner, W., Gruenberger, M., Hoefler, H., Hopewell, J., Mancuso, M., Mothersill, C., Potten, C.S., Quintanilla-Fend, L., Rozell, B., Sariola, H., Sundberg, J.P., Ward, A., 2004. Pathbase: a database of mutant mouse pathology. Nucleic Acids Res 32, D512-D515.

Shafizadeh, E., Paw, B.H., 2004. Zebrafish as a model of human hematologic disorders. Curr. Opin. Hematol. 11, 255-261.

Shima, A., Shimada, A., 1994. The Japanese medaka, Oryzias latipes, as a new model organism for studying environmental germ-cell mutagenesis. Environ. Health Perspect. 102, 33-35 Suppl 12.
Shumway, S.E., Parsons, J., 2006. Scallops: Biology, Ecology and Aquaculture, Second Edition. Elsevier, Amsterdam.

Sindermann, C.J., 1990. Principal Diseases of Marine Fish and Shellfish, Volumes 1 and 2, 2nd ed. Academic Press, San Diego, CA.

Smith, L.S., Bell, G.R., 1976. A Practical Guide to the Anatomy and Physiology of Pacific Salmon. Department of the Environment, Fisheries and Marine Service, Ottawa, Canada, Ottawa, Ontario, Canada.

Soules, K.A., Link, B.A., 2005. Morphogenesis of the anterior segment in the zebrafish eye. BMC Dev. Biol. 5, 12.

Sparks, A.K., 1985. Synopsis of Invertebrate Pathology: Exclusive of Insects. Elsevier Science Publishers, NY, NY.

Spitsbergen, J., 2007. Imaging neoplasia in zebrafish. Nat. Methods 4, 548-549.

Spitsbergen, J.M., Kent, M.L., 2003. The state of the art of the zebrafish model for toxicology and toxicologic pathology research-advantages and current limitations. Toxicol. Pathol. 31, 62-87 Suppl.

Spitsbergen, J.M., Kent, M.L., Bishop-Stewart, J., Miller, T., Matthews, J., Buhler, D.R., 2002. Spontaneous and carcinogen-induced neoplasia and other lesions in wildtype and mutant lines of zebrafish. Fifth International Meeting on Zebrafish Development and Genetics. University of Wisconsin, Madison, WI, p. 509.

Spitsbergen, J.M., Buhler, D.R., Miller, T., 2004. Another long fin and uma mutant lines are highly sensitive to polycyclic aromatic hydrocarbon-induced liver neoplasia. Sixth International Conference on Zebrafish Development and Genetics. University of Wisconsin, Madison, WI, p. 520

Sprague, J., Bayraktaroglu, L., Bradford, Y., Conlin, T., Dunn, N., Fashena, D., Frazer, K., Haendel, M., Howe, D.G., Knight, J., Mani, P., Moxon, S.A., Pich, C., Ramachandran, S., Schaper, K., Segerdell, E., Shao, X., Singer, A., Song, P., Sprunger, B., Van Slyke, C.E., Westerfield, M., 2008. The zebrafish information network: the zebrafish model organism database provides expanded support for genotypes and phenotypes. Nucleic Acids Res. 36, D768-772.

Steffen, L.S., Guyon, J.R., Vogel, E.D., Beltre, R., Pusack, T.J., Zhou, Y., Zon, L.I., Kunkel, L.M., 2007. Zebrafish orthologs of human muscular dystrophy genes. BMC Genomics 8, 79.

Stentiford, G.D., Viant, M.R., Ward, D.G., Johnson, P.J., Martin, A., Wenbin, W., Cooper, H.J., Lyons, B.P., Feist, S.W., 2005. Liver tumors in wild flatfish: a histopathological, proteomic, and metabolomic study. Omics 9, 281-299.

Stoletov, K., Klemke, R., 2008. Catch of the day: zebrafish as a human cancer model. Oncogene 27, 4509-4520.

Stoletov, K., Montel, V., Lester, R.D., Gonias, S.L., Klemke, R., 2007. High-resolution imaging of the dynamic tumor cell vascular interface in transparent zebrafish. Proc. Natl. Acad. Sci. U. S. A. 104, 17406-17411.

Stoskopf, 1993. Fish Medicine. W.B. Saunders Company, Philadelphia, PA.

Sullivan-Brown, J., Schottenfeld, J., Okabe, N., Hostetter, C.L., Serluca, F.C., Thiberge, S.Y., Burdine, R.D., 2008. Zebrafish mutations affecting cilia motility share similar cystic phenotypes and suggest a mechanism of cyst formation that differs from pkd2 morphants. Dev. Biol. 314, 261-275.

Sundberg, J.P., Sundberg, B.A., Beamer, W.G., 1997. Comparison of chemical carcinogen skin tumor induction efficacy in inbred, mutant, and hybrid strains of mice: morphologic variations of induced tumors and absence of a papillomavirus cocarcinogen. Mol. Carcinog. 20, 19-32.

Takashima, F., Hibiya, T., 1995. An Atlas of Fish Histology: Normal and Pathological Features. Kodansha, Ltd., Tokyo, Japan.

Tsao-Wu, G.S., Weber, C.H., Budgeon, L.R., Cheng, K.C., 1998. Agarose-embedded tissue arrays for histologic and genetic analysis. Biotechniques 25, 614-618.

USEPA, 1992. Framework for Ecological Risk Assessment. U.S. Environmental Protection Agency, Risk Assessment Forum, Washington, D.C. EPA/630/R-92-001.

Vasquez, S.X., Hansen, M.S., Bahadur, A.N., Hockin, M.F., Kindlmann, G.L., Nevell, L., Wu, I.Q., Grunwald, D.J., Weinstein, D.M., Jones, G.M., Johnson, C.R., Vandeberg, J.L., Capecchi, M.R., Keller, C., 2008. Optimization of volumetric computed tomography for skeletal analysis of model genetic organisms. Anat. Rec. (Hoboken) 291, 475-487.

Wei, Y., Liu, Y., Wang, J., Tao, Y., Dai, J., 2008. Toxicogenomic analysis of the hepatic effects of perfluorooctanoic acid on rare minnows (Gobiocypris rarus). Toxicol. Appl. Pharmacol. 226, 285-297.

Wen, L., Wei, W., Gu, W., Huang, P., Ren, X., Zhang, Z., Zhu, Z., Lin, S., Zhang, B., 2008. Visualization of monoaminergic neurons and neurotoxicity of MPTP in live transgenic zebrafish. Dev. Biol. 314, 84-92.

Willemse, J.J., 1979. Guide to the internal morphology of the European eel, Anguilla anguilla (L.) (Pisces, Teleostei). Aquaculture 17, 91-103.

Worm, B., Barbier, E.B., Beaumont, N., Duffy, J.E., Folke, C., Halpern, B.S., Jackson, J.B., Lotze, H.K., Micheli, F., Palumbi, S.R., Sala, E., Selkoe, K.A., Stachowicz, J.J., Watson, R., 2006. Impacts of biodiversity loss on ocean ecosystem services. Science 314, 787-790.

Wright, D., Nakamichi, R., Krause, J., Butlin, R.K., 2006. QTL analysis of behavioral and morphological differentiation between wild and laboratory zebrafish (Danio rerio). Behav. Genet. 36, 271-284.

Wu, M., Chaudhary, A., Khan, I.A., Dasmahapatra, A.K., 2008. Ethanol teratogenesis in Japanese medaka: effects at the cellular level. Comp. Biochem. Physiol., B Biochem. Mol. Biol. 149, 191-201.

Wullimann, M.F., Rupp, B., Reichert, H., 1996. Neuroanatomy of the Zebrafish Brain. Birkhauser Verlag, Basel, Switzerland.

Yasutake, W.T., Wales, J.H., 1983. Microscopic Anatomy of Salmonids: An Atlas. U.S. Dept. of the Interior, Fish and Wildlife Service, Washington, D.C.

Zon, L.I., Peterson, R.T., 2005. In vivo drug discovery in the zebrafish. Nat. Rev. Drug Discov. 4, 35-44. 